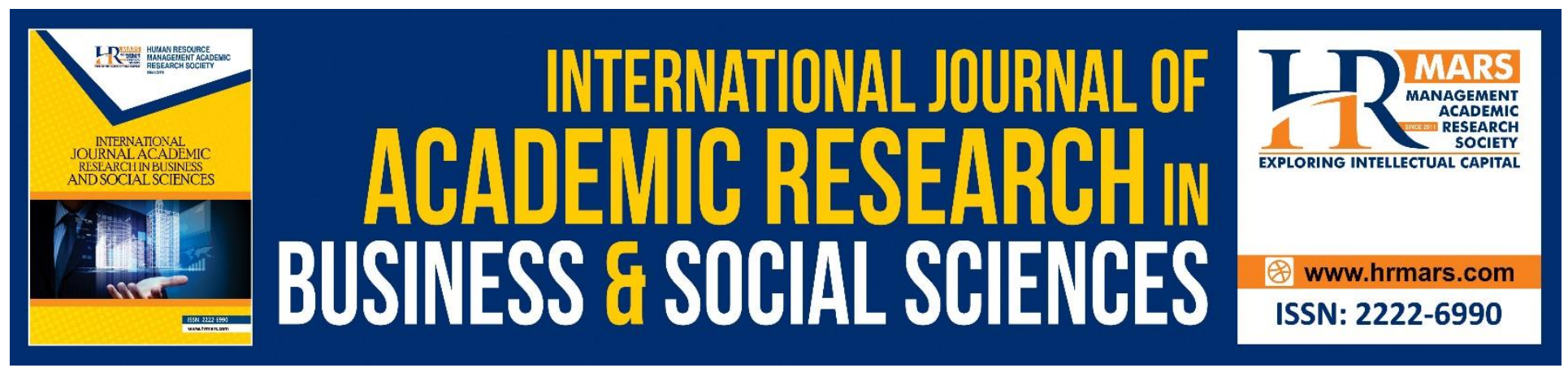

\title{
Multi-local Living and New Rural Household Structures. An Insight from Sarawak, Malaysia
}

\section{Regina Garai Abdullah}

To Link this Article: http://dx.doi.org/10.6007/IJARBSS/v11-i14/8558

DOI:10.6007/IJARBSS/v11-i14/8558

Received: 06 November 2020, Revised: 01 December 2020, Accepted: 27 December 2020

Published Online: 21 January 2021

In-Text Citation: (Abdullah, 2021)

To Cite this Article: Abdullah, R. G. (2021). Multi-local Living and New Rural Household Structures. An Insight from Sarawak, Malaysia. International Journal of Academic Research in Business and Social Sciences, 11(14), 154-163.

Copyright: (C) 2021 The Author(s)

Published by Human Resource Management Academic Research Society (www.hrmars.com)

This article is published under the Creative Commons Attribution (CC BY 4.0) license. Anyone may reproduce, distribute, translate and create derivative works of this article (for both commercial and non-commercial purposes), subject to full attribution to the original publication and authors. The full terms of this license may be seen

at: http://creativecommons.org/licences/by/4.0/legalcode

Special Issue: Contemporary Business and Humanities Landscape Towards Sustainability, 2021, Pg. 154 - 163

Full Terms \& Conditions of access and use can be found at http://hrmars.com/index.php/pages/detail/publication-ethics 


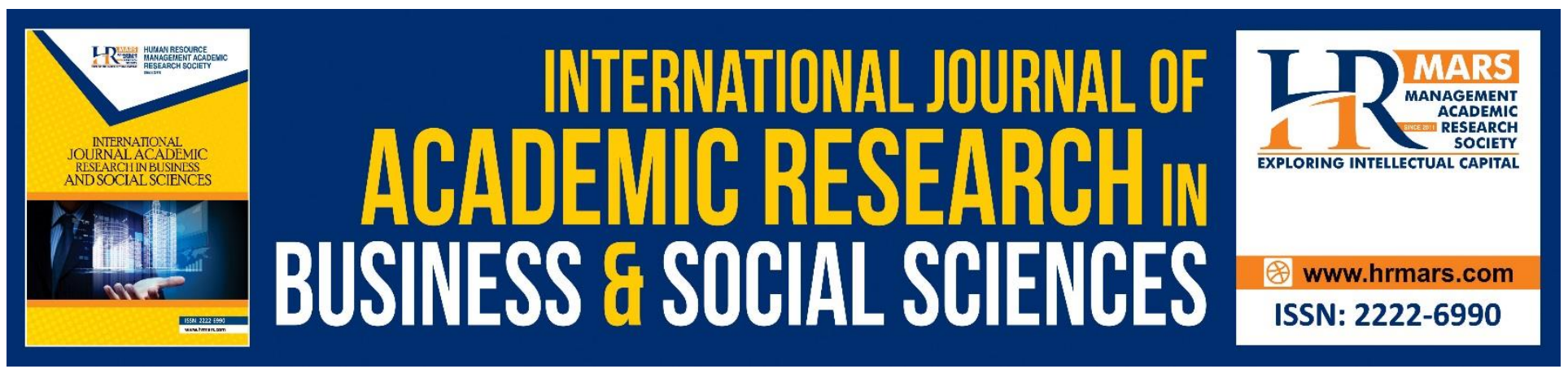

\title{
Multi-local Living and New Rural Household Structures. An Insight from Sarawak, Malaysia
}

\author{
Regina Garai Abdullah
}

Faculty of Social Sciences and Humanities, Universiti Malaysia Sarawak, Kota Samarahan, Sarawak Email: argarai@unimas.my

\begin{abstract}
This paper explores the implication of multi-local living practice on rural household structure, focusing on rural Sarawak, Malaysia. Increasing number of rural dwellers, especially the younger and more educated members, are opting for multi-local living to pursue better standard of living. Multilocal living refers to a practice where members of a household are spatially separately, either temporarily or permanently, while at the same time, remain as member of their household. The nature of the subject suits the Sociology of Everyday Life approach that is used to frame this study. Findings are based on the interviews of 82 head of households from 20 villages in rural Sarawak. Data was collected using qualitative methods, mainly in-depth interviews and focus group discussions and a set of database containing profiles of the members of each sampled households were obtained. Findings indicated that multi-local living has been widely practiced by the lban community in rural Sarawak for decades. This practice changes the traditional structure of Iban rural households (known as bilik-family) and three new forms of household structure had emerged. They are: a small bilikfamily unit, a contemporary bilik-family unit, and a large extended contemporary bilik-family unit. It is also found that the bilik-family is getting larger but the number of members actually living in the village home is quite small. This situation arises because most of the household members are spread out geographically, and yet, despite the distance and their almost semi-permanent urban resident status, they remain as acknowledged members of their respective bilik-family.
\end{abstract}

Keywords: Bilik-Family, Household Structure, Multi-Local Living, Rural Development, Sarawak.

\section{Introduction}

An increasing number of individuals are practicing multi-local living, by moving between locations, mainly in their quest for improved standard of living. The term 'multi-local living' has been associated with a 'social practice which allows people to pursue their interests in different places' (Wood, Hilti, Kramer \& Schier, 2015, p.364) or 'a practice that enables an individual to live one's life across two or more locations' (Schier, Schlinzig \& Montanari, 2015, p.426). In other words, multi-local living is characterised by the spatial dispersion of a household. The practice is widely adopted globally and in 
different forms. In the West, the focus of multi-local living practices is very much associated with multiple home ownership, which includes holiday homes, second home and/or weekend home (Weichhart, 2015). Meanwhile in the Southeast Asian countries, multi-local living practice is synonym with diversifying a family's sources of income and/or for a pursuit of better standard of living (Cramb, 2012; Fan, Sun, \& Zheng, 2011; Ngidang, 2012; Rigg \& Salamanca, 2011)

In this paper, multi-local living refers to a practice where member(s) of a household live separately from their main home, usually located in the village, either temporarily or permanently, while at the same time maintaining their membership to that original household (Abdullah, 2017, p.797)

\section{Background of the Study}

This paper focuses on the practice of multi-local living as adopted by the rural Iban in Sarawak, Malaysia. Iban is the largest ethnic group in Sarawak, with a total population of 2,868,600 in 2019 (Economic Planning Unit Sarawak, 2019). This figure accounts for approximately $28.6 \%$ of the total Sarawak population. The Iban is predominantly rural and synonym with subsistence agriculture (Cramb, 2012; Soda, 2005) but, in recent years, the number of Iban in urban areas have increased significantly. For instance, Sutlive (1992) states that, by the early 1990s, approximately 20 percent of the Iban in Sarawak has migrated to the urban areas. Recently, that figure is expected to rise drastically. However, studies on the Iban often quoted the Iban as a predominantly rural dweller and actively involved in agriculture (e.g. Berma, 2001; Cramb, 2012; Freeman, 1970; Padoch, 1982). Such assumption may be made because of the practice of multi-local living. In recent decades, Ibans who are living, almost permanently in urban areas, are still counted as rural dwellers and are still members of their bilik-family in the villages. Hence, the notion of Iban as predominantly rural dwellers.

According to Freeman (1970: 9), bilik-family is a family group, which is a basic unit of Iban social and economic organisation. He further explains that a bilik-family consists of members who are always intimately related by ties of kinship and affinity. This bilik-family actually occupies one and only one of the apartments in the longhouse. In other words, every member of the bilik-family lives under the same roof, or, as described by Freeman (1970: 9), a bilik-family constitutes as a single household. According to Freeman, the two main characteristics of a rural Iban bilik-family in the 1960s are (i) it is a small group numerically (consisting of a father, mother and children), and (ii) simple genealogically. Similarly, in his study of Iban, Sather (2006) found that a bilik-family normally consists of three generations - the parents, the children (and spouses) and their dependent children.

Those were during a period when the Iban is heavily involved in shifting cultivations and other agricultural-related activities. When de-agrarianisation occurs, the situation changes, with more and more rural Iban opting for multi-local living practices. Ngidang (2012: 171), for instance, states that,

"In the 1800s, Iban pioneers were shifting cultivators, hunters and gatherers, mobile people ...in 1900s, they became sedentary subsistence farmers ... the pioneers have long gone ... In 2000s, many of their descendants are now migrant workers and wage earners far from their homes; no longer do they subsist by working the land ..." 
This raises the question of how does the practice of multi-local living affect the structure of the rural Iban households. It should be noted that most studies on rural change in Sarawak mostly focus on issues such as rural-urban migration (Ngidang, 2012; Soda, 2005), the socio-economic implications and remittance economy (Abdullah, 2017; Cramb, 2012). What they do not address are how the household structure changes with the increasing trend of multi-local living among the Iban.

This paper will elaborate on how a simple Iban bilik-family, based on Freeman's findings in 1970, now becomes more complex using examples of households in rural Sarawak, specifically in Kapit District. Kapit is one of the most remote district in Sarawak and has a high Iban population (i.e. 59.3 percent of its total population in 2019).

\section{Methods}

Findings and discussion in this paper is based on data that was collected via qualitative methods. A total of 82 face to face interviews and two focus group discussions were conducted with head of households in 20 randomly selected villages in Kapit District. The respondents were purposively selected. Heads of households were selected as respondent as they are able to provide in-depth data relating to the bilik-family profiles, their perspectives on multi-local living and how they negotiate their own membership with their ancestral home. The interviews with head of household allow the researchers to compile a database of each member of the bilik-family from the 82 respondents. It should be noted that the discussion in the paper uses only three bilik-family units as case studies in highlighting the new types of rural Iban bilik-family structure commonly found in the case study area.

In the context of this paper, ancestral home refers to their place of origin, which is usually either their paternal or maternal village. As stated in various literature on the Iban of Sarawak, an Iban can only be a member of one bilik-family only at one time, either his/her paternal or maternal village; and in some case, the spouse's village (Cramb, 2012; Freeman, 1970; Sather, 2006; Sutlive, 1992).

Multi-local living is multi-dimensional and, therefore, has wide ranging implications from economic to social, cultural and political dimensions. The scope of this paper, however, only covers its sociocultural implications, focusing specifically on the new structure of the rural Iban bilik-family. The findings are tied to examining the phenomenon of multi-local living from the Sociology of Everyday Life (SEL) approach. This is based on the argument that the trigger for systematic research often is embedded in the context of everyday practices (Weiske, Petzold \& Schad, 2015). Exploring multi-local living using this approach enables the processes and impacts that revolve around everyday life in a household to be analysed.

\section{Results and Discussion}

In the era of de-agrarianisation, where multi-sited household is a norm, there is a clear shift in Iban household organisation. In the past, when they were still practicing traditional subsistence farming, every member of an Iban bilik-family resides under one roof in the village and everyone participates in farming activities (Cramb, 2012; Freeman, 1970; Ngidang, 2012). This situation is no longer evident in this study, especially when de-agrarianisation started to occur. Surplus labour from farming began to shift to non-farming activities, which, more often than not, are more widely available in larger 
towns and cities. Such shift resulted in multi-local living and multi-sited households (Ngidang, 2012). What used to be a single farming bilik-family living together in one geographical location is now more widespread spatially as well as in sectors other than farming. In the case study area, for instance, all of the 82 sampled households have at least one member living and staying away from the ancestral home. It is found that out of the 531 individuals (under the 82 head of bilik-families), about half of them are living elsewhere. Table 1 below shows the patterns of spatial dispersion of bilik-family members based on the findings of this study.

\begin{tabular}{|l|c|c|}
\hline \multicolumn{1}{|c|}{ Current location } & Frequency & Percentage (\%) \\
\hline Same District & 138 & 26 \\
\hline Other parts of Sarawak & 95 & 18 \\
\hline Other States in Malaysia & 44 & 8 \\
\hline Overseas & 12 & 2 \\
\hline
\end{tabular}

Table 1: Spatial dispersion of the bilik-family members

Interestingly, despite 'moving away' and setting up a home in a different geographical location, these individuals still consider themselves as member of the original bilik-family in their respective villages. Similar observation was highlighted in a number of studies on Iban in Sarawak (e.g. Abdullah, 2017; Cramb, 2012; Ngidang, 2012; Soda, 2005). In the context of Iban culture, this shift is quite significant as it affects how an individual and household view their bilik-family membership. In general, the Iban have a strong cultural attachment to their ancestral roots, which is symbolically represented by their ancestral home. Almost all of the elderly respondents argued that, traditionally, at least adult one child will inherit the ancestral home to ensure the continuity of their roots. This view is similar to the observations of rural Iban bilik-family as written by Freeman (1970) and Sather (2006). This notion of continuity in Iban bilik-family can be explained using the concept of pun (pronounced as poon).

The term 'pun' means the root or foundation of a bilik-family (Freeman, 1970). In the context of a bilik-family, pun may refer to the person who is the senior member of the bilik-family, by right of descent and who may have founded or inherited the bilik-family from the previous generation (Freeman, 1970). When an individual member of the bilik-family breaks away, he/she is creating a new pun (i.e. branching out and create a new bilik-family, away from the original bilik-family). When this happens, the original pun remains and, on top of that, another new bilik-family (pun) is created. This notion of branching out is also known as 'partitioning' (Freeman, 1970). This concept is summarised in the following Figure 1. 


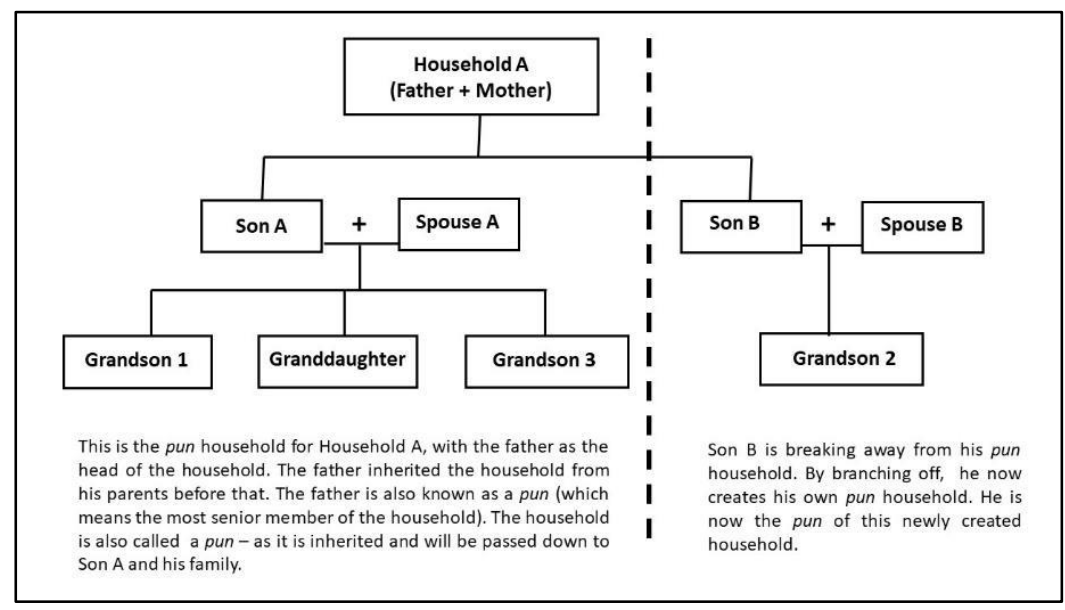

Figure 1: The Iban concept of Pun

Cramb (2012, p. 86), for instance, states that traditional forms of social organisation of the rural Iban has been maintained and adapted in the modern days. He was referring to how the Iban bilik-families in his study became spatially dispersed and yet maintaining ties with the left-behind members of their bilik-family in the village. Similarly, Soda (2005, p. 40) argues that an Iban can still belong to their ancestral bilik-family despite the fact that he/she resides outside of his/her village as long as he/she meets the membership requirement (set out by the community). This resulted in the emergence of a more complex bilik-family structure of rural Iban. This study had identified three 'new' types of bilik-family structure which differ significantly from Freeman's 'traditional' description of bilik-family. They include a small bilik-family unit, a contemporary bilik-family unit, and a large extended contemporary bilik-family unit.

\section{Small bilik-family}

A small bilik-family unit is very much similar in composition to Freeman's notion of traditional bilikfamily structure. The main difference is that the traditional bilik-family is a farming family where every member is involved in subsistence farming. The present-day small bilik-family unit, on the other hand, consists of members who are dividing their time between the village and their urban homes. Furthermore, they may not necessarily be involved in farming activities. This modern day bilik-family is illustrated by Family One, as shown in Figure 2 below. 


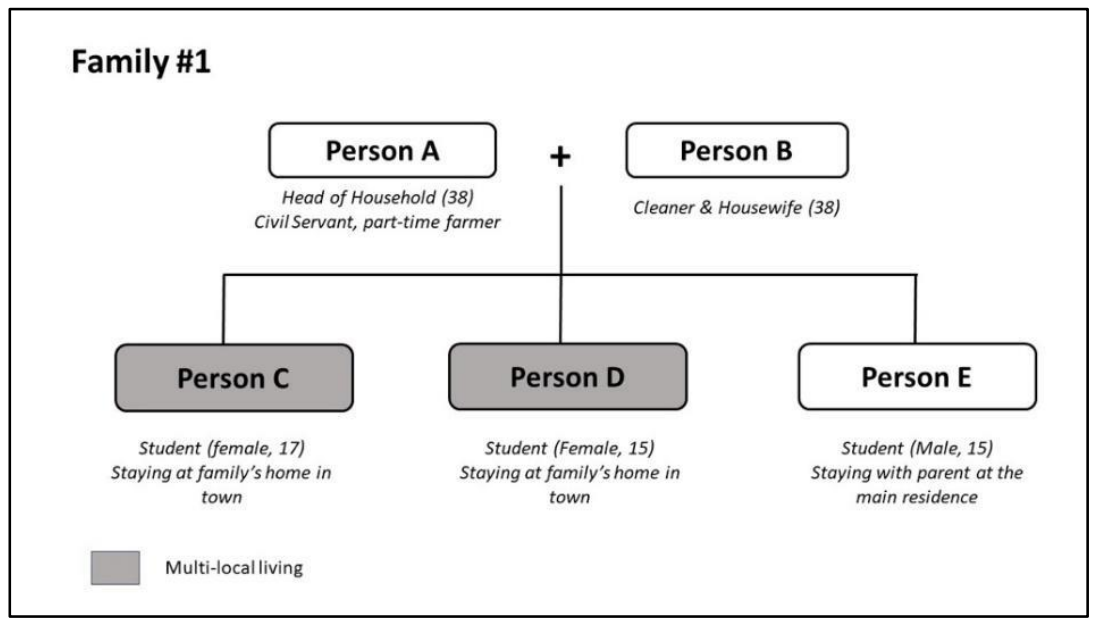

Figure 2: A small bilik-family unit

Family One has five members, and consists of a set of parents and three children. This is basically a newly formed bilik-family, whereby the father (Person A) is now the head of the bilik-family. This family branched out from their pun bilik, and constructed a house in the same village as the bilikfamily that they just separated from. The parents and their youngest child live in their village and both parents work at the nearby clinic and school respectively. Meanwhile, two of their children (Person $C$ and Person D), live in their other home which is located in the nearby town. They have to live in town as there is no secondary school in the village. In other words, the two children are practicing multi-local living for the purpose of education - they stay in town during school period but go home to their parents during school holidays and/or odd weekends. In rural Sarawak, the practice of multi-local living due to education has become an accepted norm for families with school-going children for decades.

\section{Contemporary bilik-family}

Another type of new bilik-family that was identified in this study is what I termed as a contemporary bilik-family. Freeman (1970), in his study of the Iban along the same area in 1960s, found that when the children are married, the newlyweds would normally branch out and set up their own bilik-family (i.e. similar to Family One). This study, however, found that such set up does not necessarily happen. Almost two-third of the head of households interviewed indicated that they are still very much part of their original bilik-family (still headed by their fathers or grandfathers). Furthermore, they stated that they have not 'officially' branch out of their bilik-families, despite living almost permanently in their urban homes. This is illustrated by the composition of Family Two, as shown in Figure 3 below. 


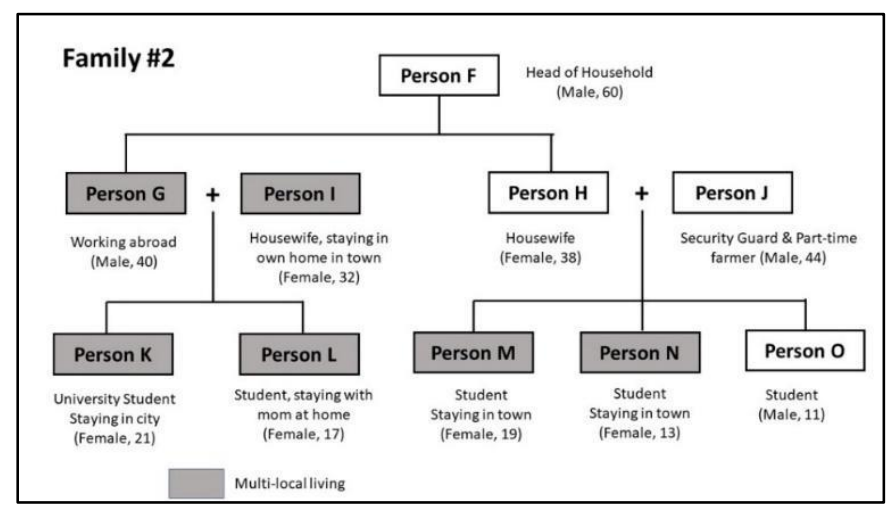

Figure 3: A contemporary bilik-family unit

Family Two consists of 10 bilik-family members, of which only four live in the ancestral home in the village. The other six are living in three different locations: Republic of Congo, Kuching (Sarawak) and Kapit town (Sarawak). Person G, who is the son of Person F, has bought a house in Kapit town, where his family (i.e. wife and children) is based. Person G himself is currently working in the Republic of Congo and would only be going back home once every two years. He has been working abroad since 2005. Her daughter (Person K) is studying at a university in Kuching and only goes home during the semester breaks. Despite the multi-locality of his family members, Person G still considers himself (and by extension, his nuclear family) part of his father's bilik-family. Neither he, nor his sister (Person $\mathrm{H}$ ) have any intention of branching out of the bilik-family anytime soon, to the delight of their father. This was not the norm decades ago as explained by Freeman (1970).

During the interview, the 60 year old head of the bilik-family had expressed how happy he is to see both his son and daughter, together with their respective families, are still part of his bilik-family. He argues that in today's environment where individuals are no longer tied up to working the land, they are more likely to venture beyond the village to search for better opportunities. This move, consequently, strengthen their family ties. Everyone is still (technically) under the same bilik-family despite their actual geographical locations. The head of the bilik-family passionately argues that, in this modern day, it is not necessary for his children to set up their own bilik-family for they always have a place in their ancestral home.

\section{Extended contemporary bilik-family unit}

Another type of bilik-family unit that was observed in this study is an extension of Family Two. As illustrated by Family Three (refer Figure 4 below), the number of individuals in one bilik-family is high and the organisation is more complex. For instance, Family Three consists of 29 individuals from four generations. Person A, has four sons (Persons B, C, D and E) and three of them has already set up their own homes in town. However, none of them had indicated that want to branch out from their pun bilik. Thus, making all their family members as members of the bilik-family headed by Person $A$. The only persons living at their ancestral home at the village is Person $A$, an 80 year old matriarch, and her 54 year old daughter-in-law, Person F. This is what I term as extended contemporary bilikfamily unit. 


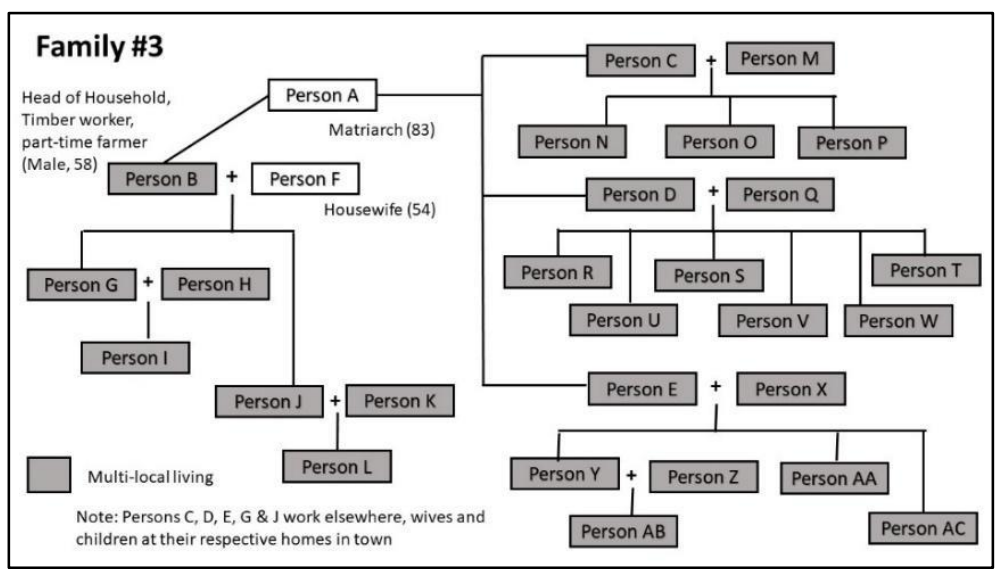

Figure 4: A large extended contemporary bilik-family unit

Interviews with the respondents indicated that, in the old days, there are rarely (if any) large bilikfamily as illustrated by Family Three. The elderly respondents (those aged 70 years old and above) explained that, in those days, by the time the children are getting married and/or have children of their own, they usually branch out from the pun bilik. In most cases, they often set out a new bilikfamily at in the same village. In modern days, however, such act of branching out does not happen as frequent as it was before. Thus, resulting in a situation where the size of the bilik-families is getting larger, but the number of people actually staying put in the village (ancestral home) is very small indeed. In most cases, those who are still living in the villages are the elderly and non-school going children.

\section{Conclusion}

The above examples of new types of bilik-families highlight how the formerly simple traditional bilikfamily structure of a rural Iban family, as observed by Freeman (1970) in the same region approximately 60 years ago, has become more complex. Firstly, the number of members in one bilikfamily has increased, as illustrated by Family Two and Family Three, but the number of members actually living in their ancestral home is much smaller than it was in the 1960s. In other words, a more flexible definition of bilik-family is now used that reflects the changes in the Iban family organisation.

The reason for this pattern is the practice of multi-local living, which allows members of the bilikfamilies to be geographically separated for a period of time but remain closely linked with their bilikfamilies. This link, in the form of membership to the bilik-family, is closely related to the notion of continuity (concept of pun) that the Iban considers as of utmost importance to the well-being of their bilik-family.

In turn, this raises the question of the future structure of rural Iban bilik-family. Those who practice multi-local living have been found to be settling down permanently in urban area despite the fact that their initial forays into urban areas were intended to be temporary. When this situation persists, it will raise another question of how the urban Iban negotiates the link that would enable them continue their membership of the bilik-family. In other words, due to the prevalence of multi-local 
living and modern practices, the concept of pun may, to a great extent, be interpreted in a different light by the Iban of Sarawak.

\section{Acknowledgement}

The author would like to thank Universiti Malaysia Sarawak (UNIMAS) for its support and funding for the research project (F06/SGS/1599/2017) and also a heartfelt gratitude to the respondents for their participation.

\section{Reference}

Abdullah, R. G. (2017). Accessibility and development. A case study from rural Sarawak, Malaysia. International Journal of Business and Society, 18(S4), 791-799

Berma, M. (2001). Constraints to rural community involvement and 'success' in non-agricultural activities: some evidence from Sarawak, Malaysia. Humanomics, 17 (1), 99-115

Cramb, R. A. (2012). Beyond the longhouse: Iban shifting cultivators come to town. In J. Rigg \& P. Vandergeest (Eds.) Revisiting rural places: Pathways to poverty and prosperity in Southeast Asia (pp.68-87). Singapore: NUS Press

Economic Planning Unit Sarawak. (2019), Sarawak facts and figures 2019. [online] Available https://jkm.sarawak.gov.my/upload/file_folder/SPU/Sarawak\%20Facts\%20\&\%20Figures\%202 019_compressed.pdf (June 28, 2020)

Fan, C. C., Sun, M., \& Zheng, S. (2011). Migration and split households: A comparison of sole, couple, and family migrants in Beijing, China. Environment and Planning - Part A, 43(9), 2164

Freeman, D. (1970). Report on the Iban. London: The Athlone Press

Ngidang, D. (2012). From frontier region to genturung pendiau. Dual residency and the making of new Iban settlements in peri-urban Kapit. Borneo Research Bulletin, 43, 162-185

Padoch, C. (1982). Migration and its alternatives among the Iban of Sarawak. The Hague: Martinus Nijhoff

Rigg, J., \& Salamanca, A. (2011). Connecting lives, living, and location. Mobility and spatial signatures in Northeast Thailand, 1982-2009. Critical Asian Studies, 43 (3), 551-575

Sather, C. (2006). "All threads are white": Iban egalitarianism reconsidered. In J.J. Fox \& C. Sather (Eds.), Origins, ancestry and alliance: Explorations in Austronesian ethnography (pp. 73-112). Canberra: Australian National University Press

Schier, M., Schlinzig, T., \& Montanari, G. (2015). The logic of multi-local living arrangements: Methodological challenges and the potential of qualitative approaches. Tijdschrift voor economische en sociale geografie, 106 (4), 425-438

Soda, R. (2005). Iban city dwellers and rural property. Sarawak Development Journal, 7 (1), 38-47

Sutlive, V. H. (1992), Chronicle of a vanishing world. Kuala Lumpur: Abdull Majeed \& Co.

Weiske, C., Petzold, K., and Schad, H. (2015) Multi-Local Living - The Approaches of Rational Choice Theory, Sociology of Everyday Life and Actor-Network Theory. Journal of Economic and Social Geography, 106 (4), 392-377

Wood, G., Hilti, N., Kramer, C., \& Schier, M. (2015). A residential perspective on multi-locality: Editorial. Tijdschrift voor economische en sociale geografie, 106 (4), 363-377 